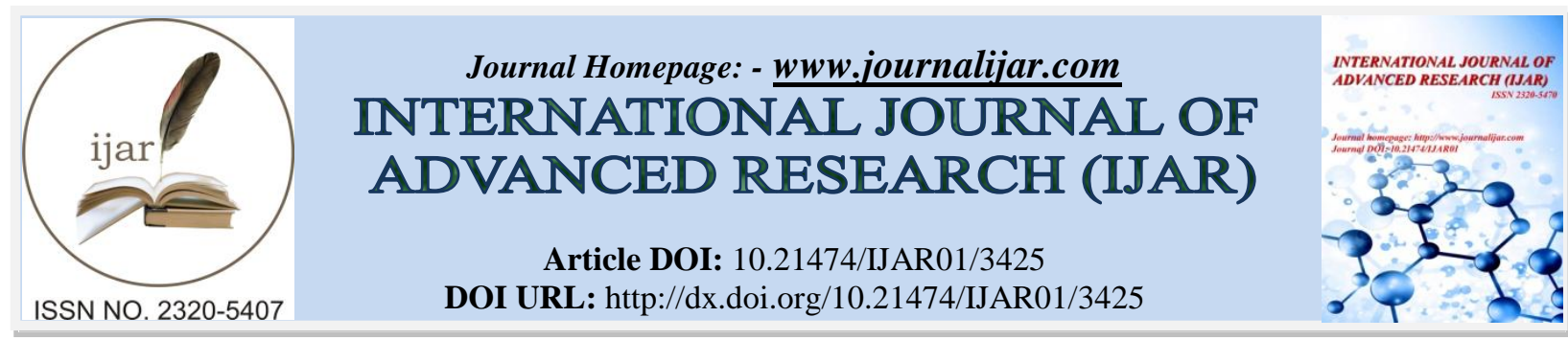

RESEARCH ARTICLE

\title{
PROTECTING BIO-INNOVATIONS: COMPARATIVE STUDY ON INNOVATION PERFORMANCE TRENDS IN INDIA AT GLOBAL LEVEL
}

1. Center for Research Studies, Noida International University.

2. School of Sciences, Noida International University, Noida, UP, India.

\section{Manuscript Info}

Manuscript History

Received: 10 December 2016

Final Accepted: 16 January 2017

Published: February 2017

\section{Key words:-}

Patent, Bio innovations, Science and technology indicators, Global Innovation Index.

\begin{abstract}
It has been long recognized that innovation performance varies considerably across nations. This observation rises immediately to important set of questions. The land mark judgment of "Diamond vs. Chakrabarty 1980 on genetically engineered bacterium changed the status of biotechnology. It has been 36 years since this landmark decision, from that time it affected the lives of virtually everyone on earth and continuous to be in the news of benefits and controversies. This revolution in biotechnology all over the world has resulted in the issuance of thousands of patents, the formation of hundreds of new companies. The objective of this study is in the context of patentability in Biotechnology, analysis of the current patent filing situation in India, PCT filing trends in the IPR. The second objective of the study is to observer the innovation performance of India on the basis of GII report 2016 in comparison with different geographic regions G7, BRICS and SAARC.
\end{abstract}

Copy Right, IJAR, 2017,. All rights reserved.

\section{Introduction:-}

Biotechnology is called as industrial Art of the biological sciences and often falls into controversies of playing with god creations, for its genetic manipulation techniques. The United Nations Convention on Biological Diversity ${ }^{1}$ as defines biotechnology as "Any technological application that uses biological systems, living organisms, or derivatives thereof, to make or modify products or processes for specific use." There are few ethical concerns and public opposition in specific areas, but overall biotechnology became a passionate research subject from past few decades and continuous to be so because of its capability of solving many problems in health and hunger. World got benefitted in medical therapies, genetic testing, crop yields and renewable fuels.

Biotech industry has recognized the potential importance of obtaining patent rights and especially where competitors are involved, enforcement of those rights. The market dynamics of world biotechnology reveals the potential of this sector. The anomaly in patenting biotechnological products arises because patent law was intended to satisfy the requirements of the industrial technology. The increasing use of patents to protect inventions by public, private and research organizations is closely connected to recent evolutions in innovation processes, economy and patent regimes. One of the compounding aspects of such laws is the relationship between the patent system and the inputs and output of biotechnology research. The issue of living organisms such as micro organisms, plants, animals, or naturally occurring substances such as DNA and proteins, cloning and bioinformatics is still a matter of concern. The biotechnology industry relies heavily on patents. This role of patents in the global economy has become part of 
a much wider discussion in terms of research, ethics, investment, business and economic development strategies. For some developing countries shifting from initially weaker patent to stronger patent system is important path of economic development. What we need to understand is that Biotechnology research and developments are never going to be end and it will continuously challenge legal and ethical issues related to it. For example the recent announcement of synthetic human genome project "HGP-write" which intended to construct human genome by synthesizing the human genome and inserting those strings into human cells growing in labs.

\section{Objectives of the study:-}

The objective of this study is in the context of patentability in Biotechnology, status of biotechnology patent filings during past few years in India, analysis of the India multi-dimensional facets of innovation performance at global level on the basis of selected parameters from Global Innovation Index report (GII-2016) ${ }^{3}$. For this purpose the study focused on international organizations G7, SAARC and BRICS group of countries with view on India. Comparison of patenting procedural variations of selected countries.

- To study the status and scenario of patents filed in office of the Controller General of Patents, India.

- To study the difference between national patent filing and International patent filing.

- To identify the Bio Innovations patentability Factors in selected countries.

- To analyze Innovation performance of selected geographic regional groups through selected parameters of Global Innovation Index report (GII-2016).

National and International Status of India in Bio-innovations: Patents are indicators of knowledge economy and innovation capacity of a country. The patent filing status of India in comparison with global level indicates output of research, industrial capacity for innovation. The requirement of such study about Indian Biotechnology gives an idea about knowledge economy relation between Indian Biotechnology research and investments. In Biotechnology sector India has quality research institutes and researchers, at the same time India gets huge R\&D investments because of large consumer base and domestic market. India had become top 12 destination in the world with 2 percent share of the global biotechnology business of the world and ranked $3^{\text {rd }}$ in Asia-Pacific region (APEC). In recent list of Global Innovation Index 2016 - 'Winning with Global Innovation' India is ranked 61. As a investment destination and as a center of research for biopharma technology industry, India is to reach $\$ 11.6$ billion by 2017according to Global Industry Analysis.

Here the study requirement is on "how to protect our biotechnology inventions and innovations of private investors in $R \& D$ institutes. Is our patent system is uniform and strong compared to global patent protection, Is there any gap in regional patent filings, research expenditure and patents filed by non residents from abroad.

Bio-Pharma technology segment continues to dominate biotech industry with big share in the overall revenue. The attractive reasons for capital investment in biotechnology are to gain market share and expanding a company's platform of products to increased efficiencies and increased R \& D potential. Increase in competition resulted significant increase in IP disputes. Patent litigation became an instrument of competition. Most commonly these disputes arises from prior art, license fees, patent infringements, misinterpreted clauses in licensing or sublicensing agreements. In global market place it is very important to seek patent protection for major inventions at least in those countries where patenting laws are very strong. Patent litigation became an instrument of competition. 
Fig 1:- Promising areas of Bio-innovations for Patents.

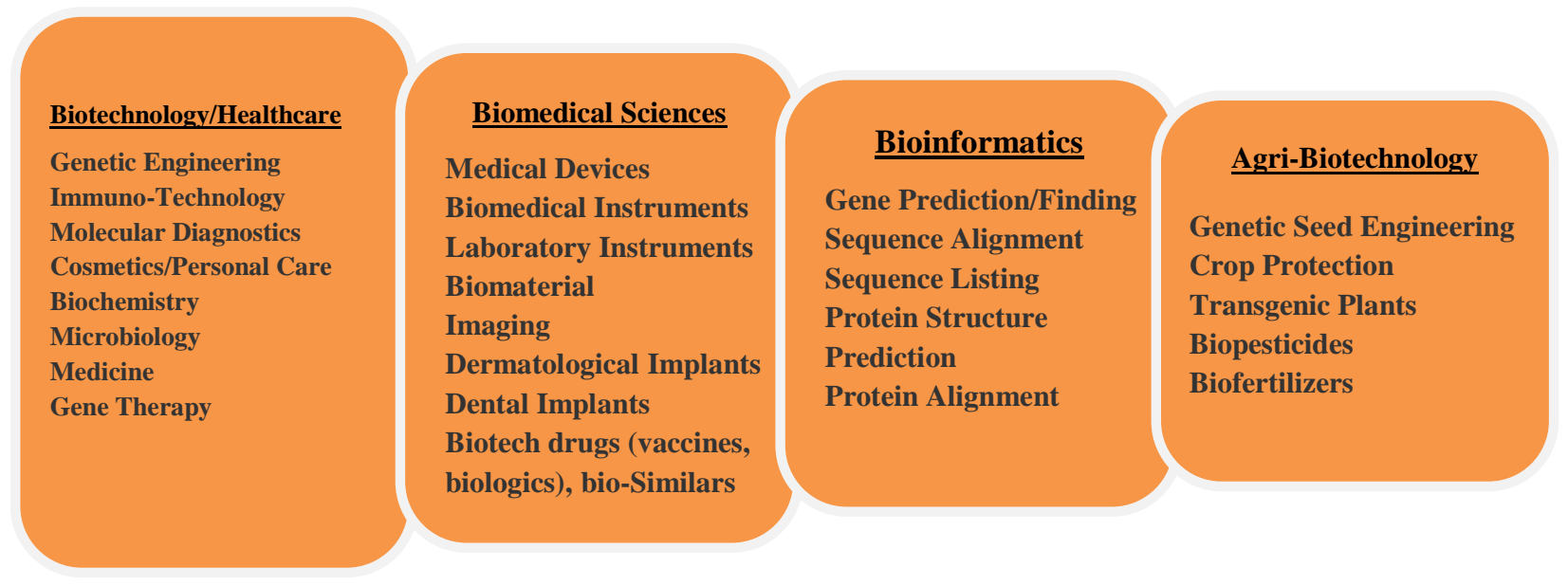

In globalized scientific research and economic competition, Indian patent law underwent significant changes during the last fifteen years. From 2005, Government of India accorded priority to IPR protection in Biotechnology. India became party to several international treaties that directly impact on biotechnology regulation and management. In respect of Patents, India is a member-state in World Trade Organization (WTO) with effect from 1995, Convention establishing World Intellectual Property Organization, (WIPO), Paris Convention for the protection of Industrial Property with effect from 1998, Patent Co-operation Treaty (PCT) with effect from 1998, Budapest Treaty with effect from 2001 responsible for the promotion of the protection of intellectual property throughout the world. In the past few years, there have been several extensive techno-legal disputes and litigations after patents were issued. The patent controversies of turmeric and basmati cases in U.S and neem by European patents office as an anti-fungal product raised important questions about the weak Indian Patenting system. These analyses points' two critical needs: India must fill the gaps in its statutory framework, and the government must build a stronger policy system.

TRIPS agreement ${ }^{4}$ was introduced to guarantee the same minimum standards of protection across countries. In India the Patents (Amendment) Act, $2002^{5}$ introduced product patent protection to all fields of technology i.e drugs, food, technology and significant changes with regard to the patentability of biotechnological inventions by specifically allowing for the patentability of microorganisms with the requirement of article 27.3(b) of the TRIPS Agreement. Plant breeder's rights received official international recognition in 1961 at Paris International Convention for the Protection of New Varieties of Plants, called UPOV.

\section{Bio Innovations patentability factors:-}

The comparative look at the procedure in patentability for Bio-innovations and patent is particularly important because of IP's impact on research are particularly crucial to the companies which want to invest in R \& D activities in biotechnology and to expand its biotech business internationally. It is important for them to understand the differences. This biotechnology assessment of IP trends will help in taking decision on investment or choosing the country for protection. Another trend in expansion of biotechnology business is international collaborations in research and technology transfer. Tech transfer trends often reflect foreign investments in biotech. "If any Indian company wanted to expand its base in other part of the world, ex. in South Africa, then the Indian company must know the Biotech regulations and Patent protection of that particular geographic country. 


\begin{tabular}{|c|c|c|c|}
\hline Country & $\begin{array}{c}\text { Types of protection } \\
\text { for } \\
\text { inventions }\end{array}$ & Term of protection & $\begin{array}{l}\text { Subject matters excluded } \\
\text { from patentability or not } \\
\text { considered to be inventions }\end{array}$ \\
\hline India & Patents & $\begin{array}{l}20 \text { years from the date of filing } \\
\text { Extension of patent term is not possible }\end{array}$ & \multirow{7}{*}{$\begin{array}{l}\text { Excluded from } \\
\text { patentability: } \\
\text { - Plant and animals varieties } \\
\text { - Inventions contrary to } \\
\text { morality/public order } \\
\text { _ not considered to be } \\
\text { inventions: } \\
\text { - Discoveries } \\
\text { - Isolated parts of human } \\
\text { beings } \\
\text {-Traditional knowledge } \\
\text { - Scientific } \\
\text { theories/mathematical } \\
\text { methods } \\
\text { - Presentation of information } \\
\text { Not considered to be } \\
\text { inventions: } \\
\text { - Discoveries } \\
\text { - Scientific } \\
\text { theories/mathematical } \\
\text { methods } \\
\text { - Diagnostic, therapeutic and } \\
\text { surgical methods for the } \\
\text { treatment of humans and } \\
\text { animals }\end{array}$} \\
\hline $\begin{array}{l}\text { South } \\
\text { Africa }\end{array}$ & Patents & $\begin{array}{l}20 \text { years from the date of filing } \\
\text { Extension of patent term is not possible. }\end{array}$ & \\
\hline Japan & $\begin{array}{l}\text { Patents } \\
\text { Utility models }\end{array}$ & $\begin{array}{l}\text { Patents: } 20 \text { years from the filing date } \\
\text { Extension of patent term is possible on: } \\
\text { Regulatory approval for pharmaceuticals } \\
\text { Regulatory approval for agricultural } \\
\text { chemicals }\end{array}$ & \\
\hline Denmark & $\begin{array}{l}\text { Patents } \\
\text { Utility models }\end{array}$ & $\begin{array}{l}\text { Patents: } 20 \text { years } \\
\text { Utility models: } 10 \text { years } \\
\text { Extension of patent term is possible on } \\
\text { the following grounds: } \\
\text { Regulatory approval for pharmaceuticals } \\
\text { Regulatory approval for agricultural } \\
\text { chemicals }\end{array}$ & \\
\hline Germany & $\begin{array}{l}\text { Patents } \\
\text { Utility models }\end{array}$ & $\begin{array}{l}\text { Patents: } 20 \text { years } \\
\text { Utility models: } 10 \text { years } \\
\text { Extension of patent term is possible on } \\
\text { the following grounds: } \\
\text { Supplementary protection certificates } \\
\text { based. }\end{array}$ & \\
\hline $\begin{array}{l}\text { United } \\
\text { states of } \\
\text { America }\end{array}$ & $\begin{array}{l}\text { Patents } \\
\text { Trade secrets } \\
\text { Design patents }\end{array}$ & $\begin{array}{l}\text { Patents: } 20 \text { years from the filing date } \\
\text { Trade secrets: indefinite } \\
\text { Design patents: } 14 \text { years from the date of } \\
\text { grant } \\
\text { Extension of patent term is possible on } \\
\text { the following grounds: } \\
\text { Regulatory approval for pharmaceuticals } \\
\text { Patent Office delay }\end{array}$ & \\
\hline $\begin{array}{l}\text { Republic of } \\
\text { Korea }\end{array}$ & $\begin{array}{l}\text { Patents } \\
\text { Utility models }\end{array}$ & $\begin{array}{l}\text { Patents: } 20 \text { years from the filing date } \\
\text { Utility models: } 10 \text { years from the filing } \\
\text { date } \\
\text { Extension of patent term is possible on } \\
\text { the following grounds: } \\
\text { Regulatory approval for pharmaceuticals } \\
\text { Regulatory approval for agricultural } \\
\text { chemicals }\end{array}$ & \\
\hline
\end{tabular}

The studies on comparing different countries patent systems will provide information on uniformity of International procedures and minute differences in national patent laws, regulatory regimes, IP barriers, differences and requirements of labelling bio products. In international patent filings there are many other issues which are common in patent industry across nations trying to solve are differing judicial standards for enforcement, compulsory licensing, adequate data protection patent office inefficiency and infringement.

India at Bio-Patents and Procedure for Patent filing:-

The TRIPS agreement which came into effect on January 1, 1995 harmonized the process of patenting of all WTO member countries at global level. TRIPS established the minimum standards for patentability and covers areas from pharmaceuticals to information technology, business practices to human gene sequences. The most relevant provision is Article 27 of TRIPS regarding patentable subject matter. Article 27.1 sets up the three basic patentability requirements, i.e., novelty, inventive step (non-obviousness) and industrial applicability (utility). The 
patenting of life-forms and living processes is covered under Article 27 sets down minimum standards for many forms of IP regulation as applied to nationals of WTO Members.

The fundamental requirement for a patent is Novelty, patentable subject matter, Inventive Step (Non-Obviousness) and Industrial applicability. Any invention is new when it is not anticipated by prior art. The Sufficient Disclosure of an invention, disclosed in the application to patent office, an inventor will obtain rights on the invention after going through established procedure. In India the Patent Office, under the Department of Industrial Policy \& Promotion (DIPP), Ministry of Commerce \& Industry, performs the statutory duties in connection with the grant of patents for new inventions and registration of industrial designs. The Patent System in India is governed by the Patents Act, 1970 (No. 39 of 1970) as amended by the Patents (Amendment) Act, 2005 necessitated by India's obligations under TRPS. Indian IP rules were amended 2003, 2005, 2006, 2012, 2013, 2014 \& 2016.

Patent rights were granted by each country through their national offices but one needs to understand that except in case of PCT applications, the patents issued by national patent office's provides a statutory right to the owner to stop others from using, selling or working out his invention, and exploit it commercially only within the territorial limits of the country for almost 20years.

The PCT application elaborately called as Patent cooperation treaty is a procedure established by WIPO to match the needs of inventors and business investors to protect their inventions in chosen countries required for them with a single application filing at regional office (RO). The advantage patent system is mainly to protect inventor's right and avoid duplication.

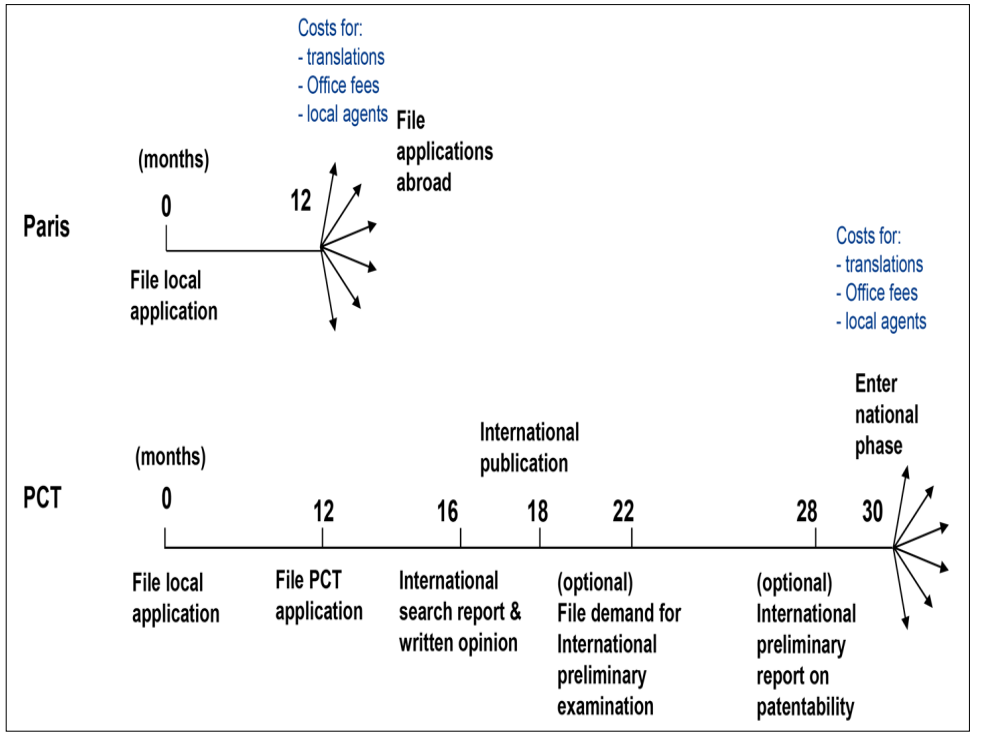

Fig 2:- International patent Filing. Paris and PCT Route. Image courtesy: http://www.wipo.int/pct/en/faqs/faqs.html

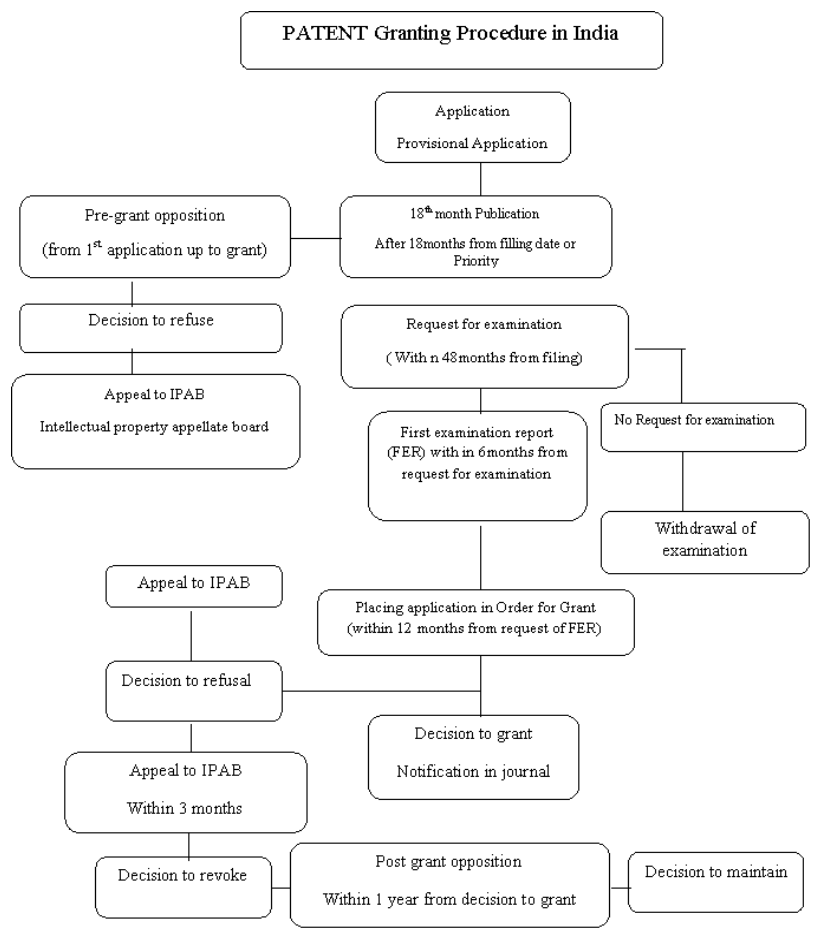

Fig 3:- Patent Filing procedure in India.

In India the patent act was enshrined in the Patents Act, 1970. The rights granted by IP office India is operative only in India. The patent process starts with an application by the true and first inventor(s) alone or jointly the applicant in the Indian Patent Office. Rules, procedures, form numbers, processing fee is fallowed as per provisions of the India patent Act 1970 (Fig-3). Only one patent will be issued for one invention on the basis of three prerequisites, novelty' 'non-obviousness' or 'inventive step' and industrial applicability to align it with the definition of article 27 of the TRIPS. Inventors who required patent protection in many countries there are three basic approaches to procuring international patent protection existed (direct, traditional filing route Paris convention and Patent Cooperation Treaty (PCT) Chapter II). The World intellectual property organization WIPO International Bureau administers the process of PCT application preliminary search, evaluation, Publication on PATENTSCOPE search database and communicate documents to offices but does not grant the international patent ${ }^{6}$. The single application now can be 
transmitted to any of the designating country required by the applicant in the list of 145 member countries national patent offices. The patent is finally issued only by the national patent office of the particular country. The direct approach is filing individual applications on same date separately in every country which is expensive, Paris convention procedure which is least expensive provides advantage of 12 months of time after the first or priority filing date in any PCT contracting member country, which In PCT one can file a single "international" patent application in India as receiving office under PCT, an international treaty with more than 145 contracting states administered by WIPO. Nationals/Residents of India can file an international application with the Indian Patent Office. The PCT process is divided into two Chapters, Chapter I and Chapter II. In Chapter II application will pass through international phase which includes International Searching Authority patent search and an International Search Report. PCT has two phases, an international phase when the international applications are in the International Bureau, and national phase which is the designated country patent office. (Fig- 2).

\section{Patenting trends in India:-}

The Indian patent act Section 3 (Patent Amendment 2003) defines Patentability Criteria of Novelty, Inventive step, Industrial applicability. The trend in India patent filings are published in the annual report of Controller General of Patents, Designs \& Trade Marks. The number of patent applications under major fields of inventions granted from 2010-11 to 2014-2015 indicates technological developments of related to chemical, food biotechnology fields related to other engineering sectors of electrical ,mechanical, general engineering and computer elated inventions. Every year the increasing number of domestic and foreign patent filings with national patent office indicates that India is emerging nation for bio research and commercialization in Biopharma, and Biotechnology. Realizing the economic importance of Biotechnology patents the government research institutes, universities and private companies are interested in getting protection for the inventions. The analysis of the patent filing trends shows the number of patent filings in Biotechnology is in the increasing trend and in 2014-2015 out of 1297 patent applications 262 patents were granted.(Fig-4\&5). Among top Indian applicants (Institutes / Universities) Indian Institute of Technology (IIT) tops with 337 patents. In scientific research organizations, Council of scientific \& industrial research (CSIR) is second with 317 patents followed by DRDO with 98 patents, ICAR with 68 patents. ( Fig-7). In top ten PCT patent filings by foreign inventors at India National patent office, United States tops the list with 8,237 applications fallowed by Japan, Germany, and Netherlands. (Fig-6).

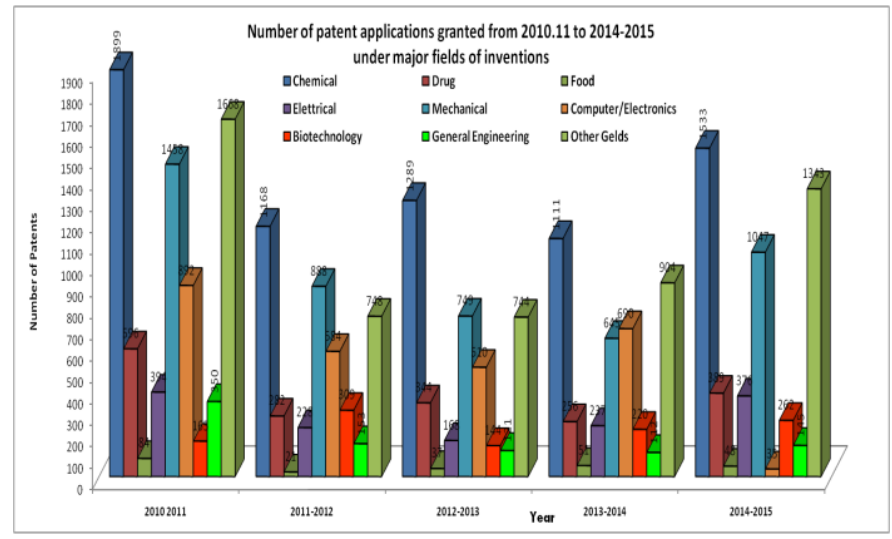

Fig 4:- Number of patent applications filed from 2010-11 to 2014-15 under major fields

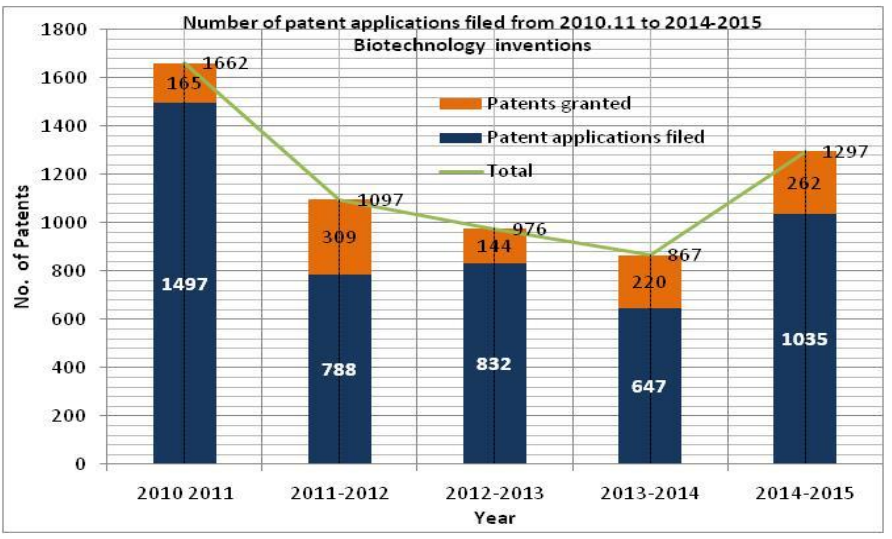

Fig 5:- Number of Biotechnology total patent applications Filed and granted from 2010-11 to 2014-15 in Indian. 


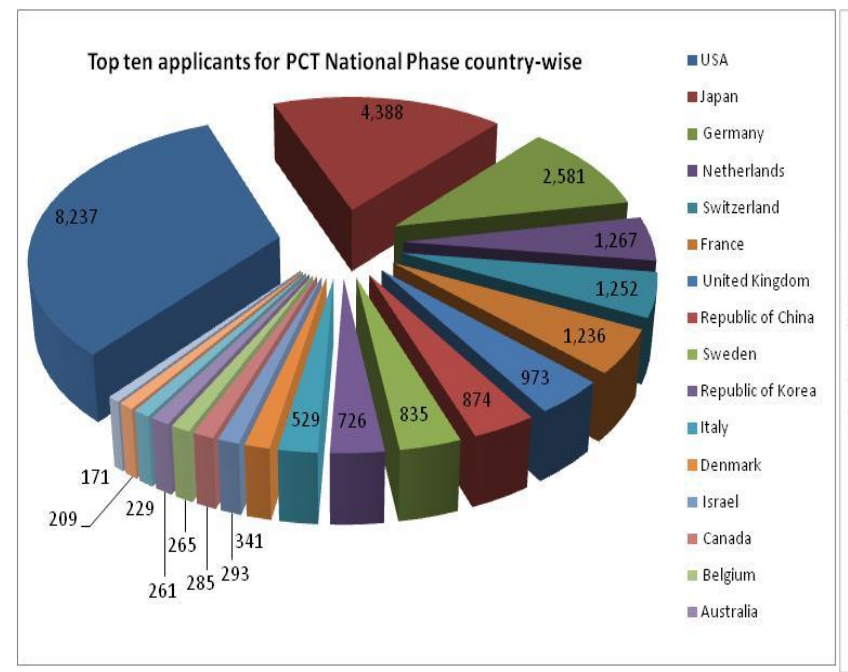

Fig 6:- Top applicant countries for PCT National Phase in India

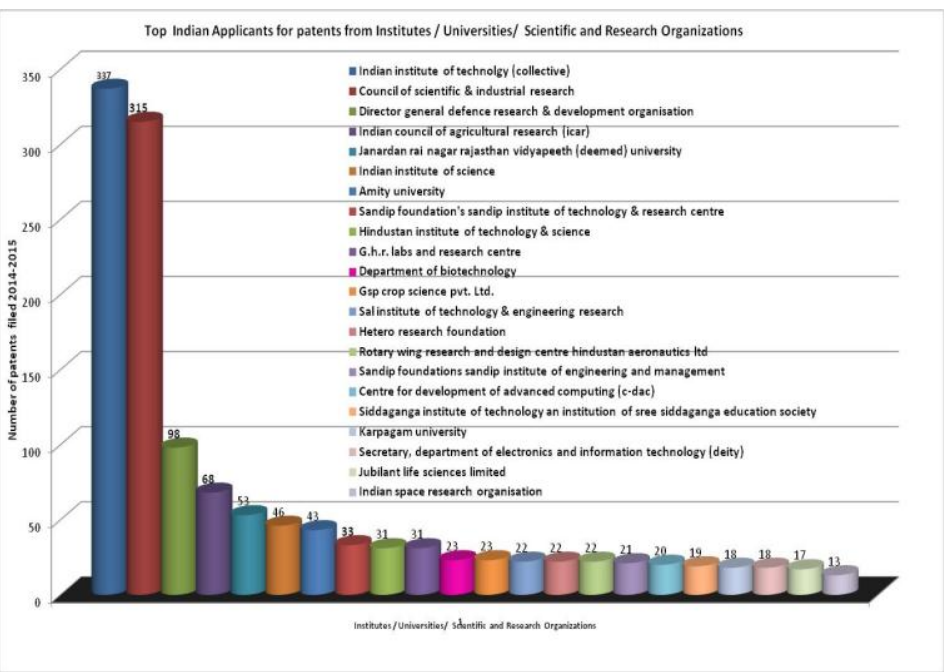

Fig 7:- Top Indian Applicants for Patents from Institutes and Universities

\begin{abstract}
Analysis:-
The research collaborations with universities, private funding from companies in universities should be encouraged. Government should improve measures to improve a systematic mechanism to produce more patents and entrepreneurs from Bio sector. India is signatory to many conventions in Biotechnology innovations, ethical committees, rights groups. India have an image of good market for Bio-Pharma, Bio-Agriculture and Bio-energy sectors, this image will improve more if India focuses on Patenting system ,encouraging domestic patent filing by the researchers will improve the status. To improve innovation performance research and development funding expenditure from Gross domestic product (GDP) is important but this alone will not improve India status. Protection of intangible assets and innovation absorption is also important. In India the connectivity between universities, funding agencies and Industries is not promoted much. To improve the domestic patent filings by Indian researchers combination of Publication-Patent concept should be encouraged with legal help from the institution .The more industry collaborations and doctoral research for real applied technological problems may improve innovations. Innovation promotes more innovation, so promotion technology transformation towards economic development. Harmonizing global mechanisms, deploying more subject specialists as patent examiners, patent analysts and quick justice to patent disputes, preventing technology infringement for patents will encourage domestic and foreign patent filings.
\end{abstract}

\title{
Innovation Performance International Trend:-
}

Innovation Performance is linked to many factors of a country. It may not be possible to calculate the value accurately but capacity of innovation performance output is possible to estimate on the basis of selected parameters. There are many international organizations like World Bank, WIPO, OECD which releases index of performance of world countries based on reports, policy studies on economic, industrial and scientific resources available. This part of the paper tried to analyze the status of India innovation performance at national level and international level comparing the selected countries geographic regional associations based on the data available on National patent office, Global Innovation Index, World Bank development indicators on science and technology.

\section{Methodology:-}

This paper evaluates the impact of innovation inputs provided and outputs mainly focusing on research and development in India. For this purpose for comparison the selected countries data where India is a member country had been analyzed as different geographic regional associations of emerging national economies, Brazil, Russia, India, China and South Africa (BRICS). The South Asian Association for Regional Cooperation (SAARC) and G7 countries. BRICS group represents fast growing economic countries of the world. The SAARC regional group where India is also a member represents developing countries. The G-7 regional bloc of industrialized democracies 
United States, United Kingdom, France, Canada, Italy, Japan, Germany are developed technologically and tops the innovations list. Comparing these countries data will give an idea on the level of inputs to be pumped in to the system to get preferable outputs. It determines the linkage between the innovation input and output parameters

THE GLOBAL INNOVATION INDEX (GII) is a yearly publication of INSEAD indicates innovation performance of the world countries on the basis of selected parameters of innovation outputs and inputs. This gives an idea for a country innovation performance to maximize the benefits from its research and development expenditures, technology creation, absorption international collaboration, the diffusion of technology knowledge across borders. For many policy makers and business leaders, this is a benchmark to perform a country towards its efforts in knowledge economy. GII index was started in 2007 by INSEAD and from past nine years and it became synonymous for reference to Innovation. In collaboration with WIPO, it is published by Cornell University, United Nations, World Bank and its knowledge partners The Confederation of Indian Industry from India. The GII report 2016 covers total 128 economies, $97.9 \%$ of global GDP and represents $92.8 \%$ of the world's population. The Global Innovation Index 2016 ranks India moving up to $66^{\text {th }}$ rank compared to its previous year rank 81 in 2015

The Innovation Index GII-Input Indicators: Research and development (R\&D), Researchers, Gross expenditure on R\&D (GERD), Global R\&D companies, average expenditure top 3, QS university ranking average score top 3 universities ,Knowledge workers, Intellectual property payments, Innovation linkages, Patent families filed in at least two offices, University/industry research collaboration, Knowledge absorption, Research talent in business enterprise

Two output pillars capture actual evidence of innovation outputs: Knowledge and technology outputs and Creative outputs. GII-Output Indicators: Knowledge impact, Knowledge diffusion, Intellectual property receipts ,Creative outputs, Intangible assets, Patent applications by origin, PCT international applications by origin , Utility model applications by origin, Knowledge and technology outputs ,Knowledge creation, Scientific and technical publications, Citable documents $\mathrm{H}$ index. This GII report helps researchers to find out country specific linkages between Public, research, innovation and technology absorption the final observations are what makes a country to transform in to regional innovator to global innovator. In many ways India is always compared with China because of demographic similarities, GDP and economic growth. The China innovation ranking is top $25^{\text {th }}$ at innovation Index and top 5 patent filing country in WIPO rankings. Brazil which is very similar economic, industrial and scientific resources is very similar outputs like to India

\section{Analyzing Global Innovation Index:-}

The Global Innovation Index 2016 with theme "Winning with Global Innovation." explores the Innovation quality and share of innovation carried out via globalized innovation networks.

The GII Indicator Rankings \& Analysis report shows list of 128 countries where Switzerland tops the list and Yemen ranked 128 is least. In the list of G7 countries which represent $46 \%$ of the global GDP, United Kingdom (3) ranks at, United States (4) in the list, Canada (15), France, Germany (10), Italy (29), Japan (16), China (25th) and most of the Southeast Asian countries are performing well. The Association of Southeast Asian Nations (ASEAN) member country Singapore ranked 6th. In contrast, no member country of the South Asian Association for Regional Cooperation (SAARC) features in the top 50. India leads the way at 61, followed by Sri Lanka (91). Nepal (115), Bhutan (96), Bangladesh (117), and Pakistan (119), all ranked 100th up or below.

India is a member country in BRICS and SAARC. The GDP of India is very high among the SAARC nations. In the SAARC regional group R\&D expenditure percentage in GDP India(0.82\%). Pakistan (0.29), Sri Lanka (0.1), Nepal (0.3) Among SAARC nations in GII innovation index India ranked at $66^{\text {th }}$ and the other nations ranks are Pakistan 119, Sri Lanka 91, Nepal (115), Bangladesh 117. In innovation performance India is showing improvement in GII index .In innovation input-parameters of knowledge absorption and innovation linkages Bhutan is doing best. In knowledge diffusion Nepal is doing better than India fallowing sustainable practices in dispensing knowledge. In intangible assets and patent applications Srilanka is doing better on performance index.

World bank Indicators among SAARC nations patent filing trends India has much gap in number of patents filed by foreign inventors and the domestic inventors, comparing with Srilanka where domestic innovators patent filing is much than the foreign inventors. India is maintaing study growth in foreign patent filings at USPTO, EPO and WIPO. This indicates India has more technological advancement and R\&D investments competing with developed 
nations. The other SAARC countries like Srilanka, Nepal, Bhutan ,Pakisthan, Bangladesh also creating favorable innovation ecosystem in producing creative out puts and protecting intangible assets.

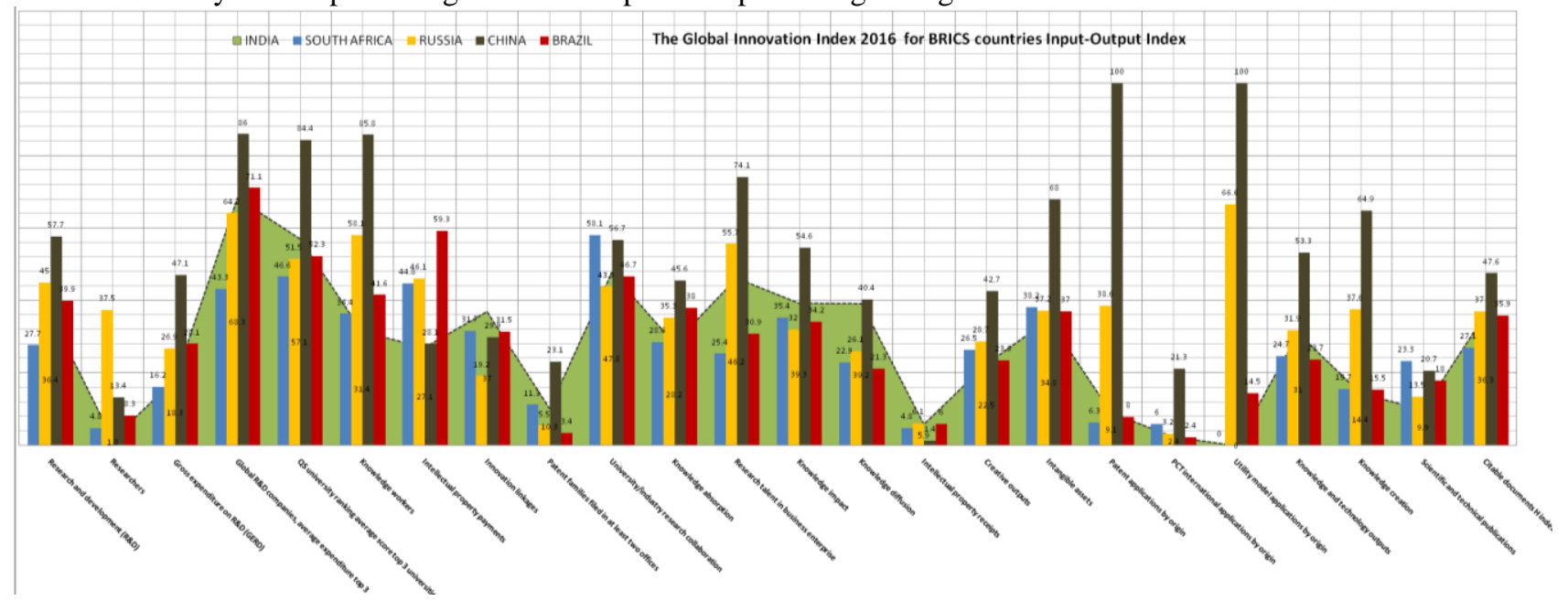

Fig 8:- The Global Innovation Index 2016 for BRICS countries Input-Output Index of selected parameters.

In the BRICS regional group R\&D expenditure percentage in GDP, China (2.05\%) is similar to the countries in G7 group. Brazil (1.24\%) and Russian Federation $(1.19 \%)$ is spending more than India $(0.82 \%)$ and South Africa(0.73\%).( Fig-10). China Innovation performance in GII index comparatively leading than rest of the four countries and in many of Input-output parameters closer to G7 group of High income countries. The other four nations were similar overall performance rankings. In Global innovation index China rank improved to $25^{\text {th }}$ and became first developing nation to reach High economic countries list in innovation performance. The four BRICS nations ranked as Russia (43), South Africa (54), India (66), Brazil (69). The G7 countries which contribute high R\&D expenditure percentage in GDP, United States (2.73\%), Japan (3.58\%), Germany (2.87\%), United Kingdom (1.7\%), France (2.26\%), Italy (1.29\%) are on top of the list in Innovation performance. United Kingdom (3), United States (4), Japan (16), Germany (10), France (18), Italy (26).

\section{Comparative analysis of Science and technology world Development Indicators:-}

The world bank every year release set of cross country comparable data of more than two hundred countries which includes more than fourteen hundred parameters is a guide to policy planners, analysts, economists and researchers ${ }^{7}$.The "Science and technology world development indicators" which provides data on number of researchers in Research and development (R\&D) working in a country per million people, productivity of Scientific and technical journal articles, Expenditures for R\&D percent of GDP Patent applications filed at national offices by residents, nonresident domestic and foreigners innovators. The statistical analysis of this data for selected countries indicates current scenario of science development in different geographic regions.(Fig-9)

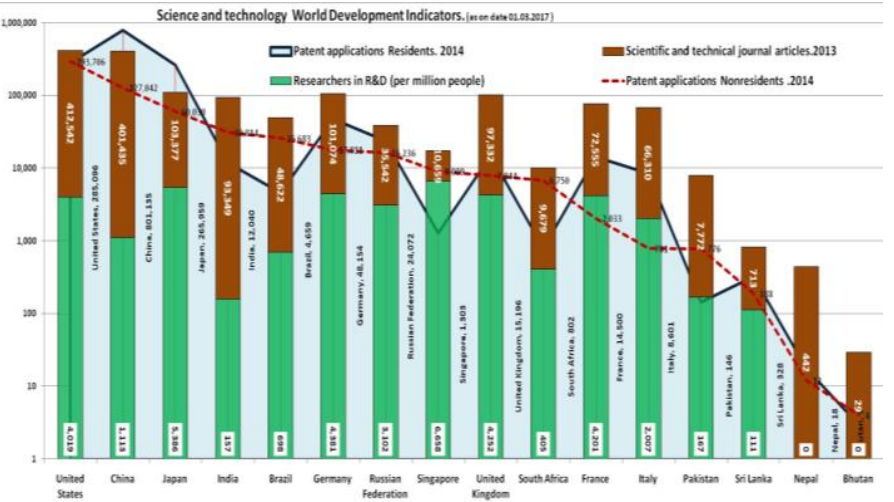

Fig 9:- Science and technology world Development Indicators of countries taken as sample (Data Source-The World bank, as on date 01.03.2017).

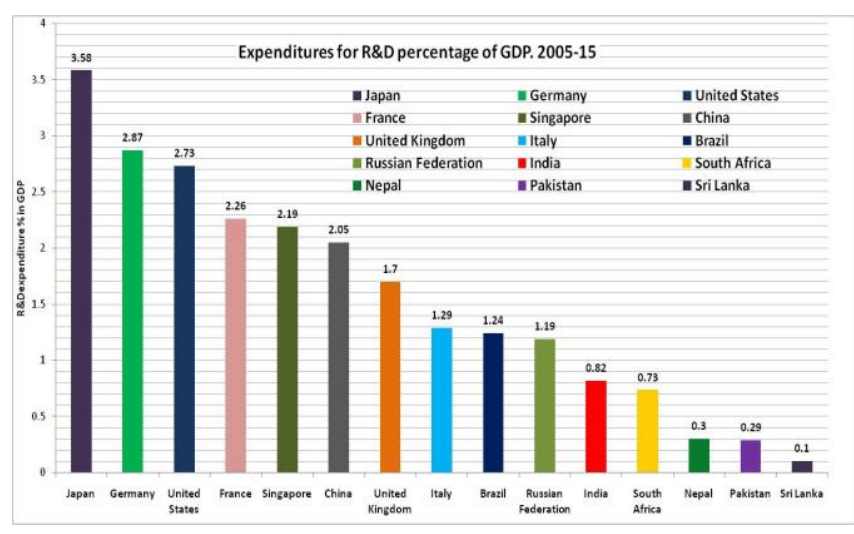

Fig 10:- Expenditures for R\&D percentage in GDP 2005-15, of countries taken as sample. 
United States, Germany, Japan and United Kingdom have maintained consistency in four observed parameters. Singapore is on top for having highest number of researchers and maintained balance between research publications and patent filings. This indicates scientific policy which optimizes technology innovation and applicability of innovations. India is least in the Researchers in R\&D (per million people) selected sample list of sixteen countries however in terms of publishing scientific publications India is in Sixth position. The number of Non-resident patent filing is more compared to the resident patent filing. China tops the list in resident patent filings which indicates aggressive patent filings and cooperative patent system for Innovators. At the same time China is in second position in patent filings by nonresidents indicates conditions of technology protection for licensing, manufacturing, technology collaborations between companies and research institutes.

\section{Conclusion:-}

The National and International filings are possible with a single application in established patent procedures according to TRIPS agreement. The Biotechnology patent filings are raising every year in India through national filings and PCT is an indication of technology transfer trends and knowledge sharing. Correlating patent filing data with R\&D Investment percentage of GDP indicating the necessity of improving Domestic patent filing by Indian residents and speedup the process of granting procedures. Spending on R\&D is important basic factor for all the countries to do better in Innovation Index. But it depends on the GDP income of a country to invest in long term innovation goal and knowledge economy. The Global Innovation Index, innovation parameters interlinked with each other. Large investment may not necessarily raise the innovation capacity. Data indicating that GDP and innovation have direct relation but optimizing basic and applied research goals, international collaborations in technology development, technology protection, improving national patent office capacity towards global standards remained as important factors. The uneven investments of low income and high income level countries has developed innovation divide. Besides investments the other important factor is increasing awareness, education and technology absorption capacity of the people. The policy changes will help to improve this crucial, vibrant and competitive knowledge economy.

\section{References:-}

1. Genome Project-write: A Grand Challenge Using Synthesis, Gene Editing and Other Technologies to Understand, Engineer and Test Living Systems November 30, 2016 Author: Jef D Boeke, George Church, Andrew Hessel, Nancy J Kelley (GP-write Leadership Group) and The GP-Write Consortium. The authors and their affiliations maybe found at www.gpwrite.org

2. The Convention on Biological Diversity, adopted during the Earth Summit in Rio de Janeiro. Legal Citation: 1760 UNTS 79; 31 ILM 818 (1992). http://www.cbd.int/convention/text.

3. The Global Innovation Index 2016: Winning with Global Innovation, Ithaca, Fontainebleau, and Geneva. Cornell University, INSEAD, and WIPO: ISSN 2263-3693.ISBN 979-10-95870-01-2.

4. The TRIPS Agreement is Annex 1C of the Marrakesh Agreement establishing the World Trade Organization, signed in Marrakesh, Morocco on 15 April 1994. Legal Citation: 1869 UNTS 299; 33 ILM 1197 (1994).

5. THE PATENTS (AMENDMENT) ACT, 2002. ACT NO. 38 OF 2002 [25th June, 2002.]. The Gazette of India. This Act came into force on 20 th May 2003 with the introduction of the new Patent Rules, 2003 by replacing the earlier Patents Rules, 1972.

6. World Intellectual Property Organization. (WIPO). PCT FAQs. Protecting your Inventions Abroad: Frequently Asked Questions About the Patent Cooperation Treaty (PCT). www.wipo.int/pct/en/filing/filing.html. http://www.wipo.int/pct/en/faqs/faqs.html.

7. World Development Indicators: Science and technology., THE WORLD BANK. As on date 01/03/2017. http://databank.worldbank.org/data/home.aspx 